Скакальская Ольга, Конищук Василий, Сасюк Андрей, Белёвский Алексей, Мнюх Александр. Находка Drosera rotundifolia L. у озера Святого (Хмельницкая область). Изучение и охрана «насекомоядныХ» растений в Украине является актуальным вопросом. Эти необычные виды растений еще недостаточно изучены и могут не только сократить численность популяций, но и исчезнуть в мировом масштабе. В статье сообщается о находке Drosera rotundifolia L. в пределах заболоченных берегов территории гидрологической памятки природы общегосударственного значения озера Святое, вошедшей в НПП «Малое Полесье» Хмельницкой области. Приведены результаты геоботанических, фитоценотических исследований, экологии места произрастания вида. Растительность представлена формациями Sphagneta magellanicum, Sphagneta cuspidatum, которые образуют ассоциации Sphagnum magellanicum + Carex rostrata + Sphagnum cuspidatum + Ledum palustre + Calla palustris + Drosera rotundifolia. Освещены данные о численности особей в ценопопуляциях на мониторинговой территории. Полученные данные свидетельствуют о благоприятных условиях для дальнейшего развития и самоподдержания популяций в ценозе. Также отмечается произростание Scheuchzerua palustris L., которая занесена в Красную книгу Украины.

Ключевые слова: фитоценоз, ассоциация, Drosera rotundifolia L., гетеротрофный вид, гелиофиты, численность, структура.

Skakal's'ka Olga, Konischuk Vasul', Sasiuk Andrii, Bilovskyy Oleksii, Mnyuh Oleksandr. Drosera Rotundifolia L. Finding the Holy Lake (Khmelnytsky Region). Study and Protection of «carnivorous» plants in Ukraine is an important issue. These unusual species of plants have not been studied and can not only reduce the number of populations and disappearing on a global scale. The article reports the discovery of Drosera rotundifolia L. within the territory of the coast wetlands hydrological nature reminder of national importance «Lake» saints», included in the NPP «Small Polesie» Khmelnitsky region. The results presented geobotanical, phytocenotic research ecology habitat species. The vegetation is represented by formations Sphagneta magellanicum, Sphagneta cuspidatum, which form the association of Sphagnum magellanicum + Carex rostrata + Sphagnum cuspidatum + Ledum palustre + Calla palustris + Drosera rotundifolia. Covered data on the number of individuals in populations at the monitoring site. The findings suggest that favorable conditions for further development and self-sustaining populations in cenosis. Also noted habitat Scheuchzeria palustris L., which is listed in the Red Book of Ukraine.

Key words: phytocoenosis, association, Drosera rotundifolia L., heterotrophic species heliofit, size, structure.

Стаття надійшла до редколегії 11.11.2015 p.

УДК 581.524.1

Вікторія Скляр

\title{
Розмірна структура підросту дуба звичайного в лісових фітоценозах Лівобережного Полісся України
}

Надана інформація про величини висоти та діаметра стовбура в особин різних груп молодого покоління дуба звичайного, наявного під наметом лісових фітоценозів 17 груп асоціацій, які є типовими для Лівобережного Полісся України. Охарактеризовано розмірну структуру трьох когорт підросту: дрібного, середнього та великого. Показано, що кожна з них у тому чи іншому лісовому фітоценозі має специфічні особливості розмірної структури. Для поглибленої оцінки розмірної структури когорт запропоновано та використано спеціальний показник: індекс різноманітності розмірної структури (IDSS). Показано, що когортам підросту дуба звичайного не притаманний високий рівень різноманітності розмірної структури: значення IDSS у більшості фітоценозів є меншими за $25 \%$. Відзначено тенденцію до зменшення різноманітності розмірної структури в міру дорослішання підросту.

Ключові слова: лісоутворювальні види, природне відновлення лісів, підріст, морфометричний аналіз, дуб звичайний.

Постановка наукової проблеми та її значення. Розмір рослинних організмів значною мірою у зв’ язку з прикріпленим способом життя є їхньою дуже важливою базовою характеристикою. Із ним безпосередньо пов'язано багато властивостей рослин, зокрема їх місце у біогеоценозі, внесок у біопродукцію, місце в комплексі внутрішньоекосистемних зв' язків $[5,16]$.

(C) Скляр В., 2015 
Розмір особин є визначальним і щодо успішності їх виживання в складі фітоценозів. Особливо значущий цей аспект для рослин молодого покоління лісоутворювальних видів, від появи, росту та розвитку яких під наметом материнського деревостану в підсумку залежать стійкість і довготривалість існування лісових угруповань загалом [10]. Отже, на сьогодні вивчення розмірних величин та розмірної структури молодого покоління лісоутворювальних видів виступає актуальною науковою проблемою, що має суттєве теоретичне й практичне значення. Проведення таких досліджень доцільне й для дуба звичайного (Quercus robur L.), який належить до провідних лісоутворювальних видів України загалом та, зокрема, для одного з найбільш заліснених його регіонів - Лівобережного Полісся.

Аналіз досліджень цієї проблеми. Незважаючи на те, що вивчення розмірних характеристик рослин уже довгий час $є$ однією з найважливіших складових частин окремих напрямів ботанічних досліджень $[6,15]$, а морфометричний аналіз застосовується під час вивчення різних рівнів організації живого (особин, популяцій, фітоценозів), на фоні наявності дуже великої кількості робіт, у яких надається інформація про розмір об'єктів вивчення, частка розробок із даними про розмірну структуру тих чи інших сукупностей рослин $\epsilon$ незначною. Хоча доцільність аналізу співвідношення у фітоценозах рослин різних розмірних груп, а також інформативність цього показника вже досить давно доведено в класичних ботанічних роботах $[2,3,17]$. Останнім часом дані про розмірну структуру ценопопуляцій рослин досить часто наводяться в роботах із функціонування лісових фітоценозів $[1,8,9,10]$ і конкурентних відносин між рослинами [7].

Мета статті - оцінити розмірні характеристики та розмірну структуру молодого покоління $Q$. robur у різних лісорослинних умовах Лівобережного Полісся України.

Завдання дослідження - визначити розмірні величини підросту в різних лісорослинних умовах, установити представленість рослин різних класів розмірності й різноманітність розмірної структури молодого покоління $Q$. robur у досліджуваних фітоценозах.

Матеріали й методи. В основу цієї публікації покладено результати досліджень, які здійснювалися на території Лівобережного Полісся України у 2002-2013 рр. Вивченням охоплено лісові фітоценози, що є типовими для цього регіону. Вони належать до 17 груп асоціацій: 1. Pineta (sylvestris) hylocomiosa; 2. Pineta (sylvestris) calamagrostidosa (epigeioris), 3. Pineta (sylvestris) coryloso (avellanae) -vacciniosa (myrtilli); 4. Pineta (sylvestris) asarosa (europaei); 5. Pineta (sylvestris) pteridiosa (aquilini); 6. Pineta (sylvestris) franguloso (alni)-vacciniosa (myrtilli); 7. Pineta (sylvestris) vacciniosa (myrtilli); 8. Pineta (sylvestris) moliniosa (caeruleae); 9. Pineta (sylvestris) sphagnosa; 10. Querceto (roboris)-Pineta (sylvestris) vacciniosa (myrtilli); 11. Querceto (roboris)-Pineta (sylvestris) corylosa (avellanae) sparsi herbosa; 12. Betuleto (pendulae)-Pineta (sylvestris) vacciniosa (myrtilli); 13. Querceta (roboris) majanthemosa (bifolii); 14. Querceta (roboris) convallariosa (majalis); 15. Querceta (roboris) coryloso (avellanae)-convallariosa (majalis); 16. Betuleta (pendulae) vacciniosa (myrtilli), 17. Betuleta (pendulae) stellariosa (holosteae).

Для оцінки стану цих угруповань і природного відновлення в них застосовано загальноприйняті геоботанічні методи $[12,14]$. Окрім того, для поглибленого аналізу стану природного відновлення лісоутворювальних видів, у тому числі й $Q$. robur, розроблено систему поділу популяцій деревних рослин на внутрішньопопуляційні структурні групи - когорти. У іiі основу покладено прийняту в лісівництві методику реєстрації молодого покоління дерев та їх дорослих особин, доповнено оцінкою розміру рослин, їхного онтогенетичного стану й положення в архітектоніці лісової екосистеми. Серед підросту виділено три типи когорт.

1. Дрібний nidpicm. Це когорта рослин, яка розміщена повністю в трав' яно-чагарниковому ярусі лісового фітоценозу. Особини мають висоту до $50 \mathrm{~cm}$, рідше - до 60-70 см. Їхня коренева система поверхнева. Календарний вік - здебільшого від 3-5 років до десятків років. За онтогенетичним станом зазвичай це ювенільні або імматурні особини.

2. Середній nidpicm. Рослини цієї когорти «виходять» із трав' яно-чагарникового ярусу й «убудовуються» в ярус підліску. Особини середнього підросту здебільшого охоплюють висотний діапазон від 0,5 м до 2,5 м. За календарним віком вони дуже різні: 10-11 і більше років. Це переважно імматурні, рідше - віргінільні рослини. Усі вони вирізняються досить швидким ростом у висоту.

3. Великий nidpicm. Особини великого підросту містяться в ярусі підліску. Порівняно з дрібним i середнім підростом, їхня коренева система розміщена в глибших шарах грунту. Здебільшого це рослини висотою 2,5-8,0 м. Їхній календарний вік - зазвичай понад 20-25 років [13].

Для оцінки стану особин кожної з когорт застосовано морфометричний аналіз $[4,5]$. Залежно від когорти він супроводжувався визначенням у рослин від трьох до 22 розмірних показників. 
Розмірна структура когорт аналізувалася з опорою на величини таких характеристик, як висота особин та діаметр стовбура. При цьому нами запропоновано й використано спеціальний показник індекс різноманітності розмірної структури (IDSS). Він $є$ вираженою у відсотках часткою від кількості виявлених у цій групі асоціацій варіантів сполучення різних розмірних класів висоти й діаметра стовбура (Nf) до загальної теоретично розрахованої кількості таких сполучень (Nt):

$$
\mathrm{IDSS}=(\mathrm{Nf} / \mathrm{Nt}) \times 100 \% .
$$

На основі аналізу величин висоти та діаметра особин $Q$. robur, а також інших лісоутворювальних видів Лівобережного Полісся України (Pinus sylvestris L., Acer platanoides L., Betula pendula Roth., Populus tremula L. та ін.) установлено, що в регіоні досліджень у підрості значення Nt для когорт великого підросту дорівнюють 38 , у середнього підросту - 29, дрібного - 42 .

Виклад основного матеріалу й обгрунтування отриманих результатів дослідження. Установлено, що дрібний підріст $Q$. robur, який формується під наметом лісових фітоценозів Лівобережного Полісся України, за висотою відповідає п’ятьом класам розмірності, а за діаметром - семи. Дійсно, особини цієї когорти переважно мають висоту не більшу за 50 см. Рослини вистою 50-70 см зареєстровано у фітоценозах лише семи груп асоціацій (Pineta (sylvestris) hylocomiosa, Pineta (sylvestris) calamagrostidosa (epigeioris), Pineta (sylvestris) pteridiosa (aquilini), Pineta (sylvestris) franguloso (alni)vacciniosa (myrtilli), Pineta (sylvestris) vacciniosa (myrtilli), Querceta (roboris) convallariosa (majalis), Querceta (roboris) coryloso (avellanae)-convallariosa (majalis)) і їх частка в цих угрупованнях зазвичай не перевищує $10 \%$. Величина діаметра стовбура в особин когорти дрібного підросту здебільшого перебуває в межах $0,1-1,5$ см.

Середній підріст $Q$. robur за висотою відповідає п'ятьом класам розмірності, а за діаметром шести. У фітоценозах двох груп асоціацій (Pineta (sylvestris) hylocomiosa, Querceta (roboris) convallariosa (majalis)) у складі цієї когорти виявлено рослини висотою 2,5-3,0 м, а в усіх інших угрупованнях вони є нижчими за 2,5 м. Розмір діаметра стовбура в середнього підросту здебільшого перебуває в межах 1,0-6,0 см.

Великий підріст $Q$. robur за величинами і висоти, і діаметра відповідає семи класам розмірності. У фітоценозах трьох груп асоціацій (Pineta (sylvestris) hylocomiosa, Pineta (sylvestris) pteridiosa (aquilini), Querceto (roboris)-Pineta (sylvestris) vacciniosa (myrtilli)) у складі цієї когорти виявлено рослини висотою 8,0-8,5 м, а в усіх інших угрупованнях величина цієї характеристики особин в основному перебуває в межах 3,0-8,0 м. Показники діаметра стовбура у великого підросту переважно варіюють від 3,5 см до 9,5 см.

Результати оцінки розмірних величин і загалом розмірної структури когорт підросту $Q$. robur у різних лісових фітоценозах Лівобережного Полісся України наведено в табл. 1-3. Інформація, надана в них, свідчить, що в досліджуваному регіоні представленість природного відновлення цього виду зменшується в ряду дрібний підріст $\rightarrow$ середній підріст $\rightarrow$ великий підріст. Так, особини першої когорти виявлено в лісах шістнадцяти груп асоціацій, другої - десяти, третьої - дев'яти.

У деяких фітоценозах під наметом наявне молоде покоління не всіх трьох когорт, а лише однієї чи двох. Зокрема, в угрупованнях груп асоціацій Pineta (sylvestris) pteridiosa (aquilini), Betuleta (pendulae) vacciniosa (myrtilli) та Betuleta (pendulae) stellariosa (holosteae) представлений лише дрібний підріст Q. robur, a Querceto (roboris)-Pineta (sylvestris) corylosa (avellanae) sparsi herbosa - виключно великий. Під наметом лісів Pineta (sylvestris) moliniosa (caeruleae), Querceta (roboris) majanthemosa (bifolii), Querceta (roboris) coryloso (avellanae)-convallariosa (majalis) відсутній великий підріст Q. robur, а під наметом Pineta (sylvestris) vacciniosa (myrtilli), Pineta (sylvestris) sphagnosa, Betuleto (pendulae)Pineta (sylvestris) vacciniosa (myrtilli) - не представлений середній.

Величини індексу різноманітності розмірної структури (IDSS) за групами асоціацій у дрібного підросту Q. robur коливаються в межах 9,5-57,1\%, у середнього - від 3,4 до 48,3\%, у великого - від 5,3 до 18,4\%. Переважно когорти мають значення IDSS, що не перевищують $25 \%$. 
Таблиия 1

Розмірна структура когорт дрібного підросту Quercus robur

\begin{tabular}{|c|c|c|c|c|c|c|c|c|c|c|c|c|c|c|c|c|c|c|c|}
\hline \multicolumn{4}{|c|}{ Морфометричні параметри } & \multirow{2}{*}{\multicolumn{16}{|c|}{$\begin{array}{c}\text { Частка особин різного розміру за групами асоціацій, \% } \\
\text { (нумерація груп асоціацій відповідає наведеній у тексті) }\end{array}$}} \\
\hline \multicolumn{2}{|r|}{ висота } & \multirow{2}{*}{\multicolumn{2}{|c|}{\begin{tabular}{|c|c}
\multicolumn{2}{|c|}{ діаметр } \\
\multirow{3}{*}{ клас } & амплітуда \\
& абсолютних \\
& значень,, м \\
\end{tabular}}} & & & & & & & & & & & & & & & & \\
\hline клас & $\begin{array}{c}\text { амплітуда } \\
\text { абсолютних } \\
\text { значень, } \boldsymbol{M}\end{array}$ & & & 1 & 2 & 3 & 4 & 5 & 6 & 7 & \multirow[t]{2}{*}{8} & \multirow[t]{2}{*}{9} & 10 & \multirow[t]{2}{*}{12} & 13 & 14 & 15 & 16 & 17 \\
\hline Ia & більше 0,5 & Ia & більше 1,2 & 0,7 & & & & & 3,8 & & & & & & & & & & \\
\hline Ia & більше 0,5 & $\mathrm{I}$ & $1,0-1,2$ & 2,3 & 9,6 & & & & 2,3 & & & & & & & & & & \\
\hline Ia & більше 0,5 & II & $0,8-1,0$ & 0,7 & 10,2 & & & & & & & & & & & & & & \\
\hline Ia & більше 0,5 & III & $0,6-0,8$ & & & & & 12,5 & 1,9 & 2,7 & & & & & & & & & \\
\hline Ia & більше 0,5 & IV & $0,4-0,6$ & 0,3 & & & & & 1,5 & & & & & & & 1,4 & 5,1 & & \\
\hline I & $0,4-0,5$ & Ia & більше 1,2 & 2,7 & & & & & 3,8 & & & & 1,3 & & 4,2 & & & & \\
\hline I & $0,4-0,5$ & I & $1,0-1,2$ & 5,0 & & & 12,8 & & 2,1 & 2,6 & & & 1,5 & & 5,8 & & 3,3 & & 3,7 \\
\hline I & $0,4-0,5$ & II & $0,8-1,0$ & 7,4 & 8,5 & & 13,7 & & 11,5 & 5,5 & & & 13,2 & 24,8 & 6,1 & 2,1 & 3,8 & 18,2 & 4,2 \\
\hline I & $0,4-0,5$ & III & $0,6-0,8$ & 9,0 & 9,7 & & 20,9 & 6,3 & 2,4 & 6,2 & & 8,6 & 3,4 & & & 4,8 & & & 5,3 \\
\hline I & $0,4-0,5$ & IV & $0,4-0,6$ & 2,0 & 12,3 & & 6,7 & & 1,7 & 11,1 & 17,8 & & & & & 6,5 & & & 7,4 \\
\hline II & $0,3-0,4$ & Ia & більше 1,2 & 2,1 & & & & & & & & & 6,8 & & & & & 8,9 & \\
\hline II & $0,3-0,4$ & I & $1,0-1,2$ & 2,3 & & & & 6,2 & 6,4 & 3,5 & & & 8,5 & & 9,3 & & & & \\
\hline II & $0,3-0,4$ & II & $0,8-1,0$ & 8,4 & 9,3 & & 5,8 & & 5,8 & 5,6 & & 16,2 & 12,7 & & 14,9 & 1,2 & & & \\
\hline II & $0,3-0,4$ & III & $0,6-0,8$ & 10,1 & & & 6,3 & & 13,5 & 2,3 & 32,4 & 8,9 & 11,9 & & 9,6 & 3,2 & 31,8 & 9,9 & 19,5 \\
\hline II & $0,3-0,4$ & IV & $0,4-0,6$ & 6,2 & 11,7 & 18,4 & 7,1 & 18,8 & 7,7 & 22,1 & 30,2 & & 13,6 & 26,1 & & 14,5 & & & 5,3 \\
\hline II & $0,3-0,4$ & $\mathrm{~V}$ & $0,2-0,4$ & 0,3 & & 21,5 & & 5,9 & & & & & & & & 1,6 & & & \\
\hline II & $0,3-0,4$ & $\mathrm{Va}$ & $0,1-0,2$ & & & & & & 0,3 & & & & & & & & & & \\
\hline III & $0,2-0,3$ & I & $1,0-1,2$ & 1,3 & & & & & & & & & 3,1 & & & & & & \\
\hline III & $0,2-0,3$ & II & $0,8-1,0$ & 3,3 & 12,7 & & & & 1,9 & & & & 4,4 & & & & & & \\
\hline III & $0,2-0,3$ & III & $0,6-0,8$ & 10,5 & & & 6,6 & & 8,6 & 2,8 & 19,6 & & 6,7 & 13,4 & 10,1 & 6,5 & 8,2 & 27,2 & 11,1 \\
\hline III & $0,2-0,3$ & IV & $0,4-0,6$ & 13,4 & & 22,8 & 20,1 & 19,3 & 9,5 & 14,5 & & 16,8 & 8,2 & 11,8 & 13,7 & 33,9 & 28,1 & 18,2 & 15,6 \\
\hline III & $0,2-0,3$ & $\mathrm{~V}$ & $0,2-0,4$ & 2,3 & 7,3 & 37,3 & & 18,8 & 3,8 & 5,6 & & & & & 4,9 & 14,5 & & & 8,2 \\
\hline IV & $0,1-0,2$ & II & $0,8-1,0$ & 0,3 & & & & & & & & & & & & & & & \\
\hline IV & $0,1-0,2$ & III & $0,6-0,8$ & 0,7 & & & & & 5,8 & & & & & & & & & & \\
\hline IV & $0,1-0,2$ & IV & $0,4-0,6$ & 3,3 & 8,7 & & & & 1,9 & 7,4 & & & 4,7 & 14,6 & 17,8 & 1,7 & 3,5 & 9,1 & \\
\hline IV & $0,1-0,2$ & $\mathrm{~V}$ & $0,2-0,4$ & 5,4 & & & & 12,2 & 3,8 & 8,1 & & 49,5 & & 9,3 & 3,6 & 8,1 & 16,2 & 8,5 & 19,7 \\
\hline $\begin{array}{l}\text { Індекс } \\
\text { (IDSS) }\end{array}$ & різноманітнос & о3мі & ної структури & 57,1 & 23,8 & 9,5 & 21,4 & 19,0 & 50,0 & 33,3 & 9,5 & 11,9 & 33,3 & 14,3 & 26,2 & 31,0 & 19,0 & 16,7 & 23,8 \\
\hline
\end{tabular}


Таблиия 2

Розмірна структура когорт середнього підросту Quercus robur

\begin{tabular}{|c|c|c|c|c|c|c|c|c|c|c|c|c|c|}
\hline \multicolumn{4}{|c|}{ Морфометричні параметри } & \multirow{2}{*}{\multicolumn{10}{|c|}{$\begin{array}{c}\text { Частка особин різного розміру за групами асоціацій, \% } \\
\text { (нумерація груп асоціацій відповідає наведеній у тексті ) }\end{array}$}} \\
\hline \multicolumn{2}{|r|}{ висота } & \multirow{2}{*}{\multicolumn{2}{|c|}{\begin{tabular}{l|l}
\multicolumn{2}{c}{ діаметр } \\
клас & амплітуда \\
& абсолютних \\
& значень,, м.
\end{tabular}}} & & & & & & & & & & \\
\hline клас & $\begin{array}{l}\text { амплітуда } \\
\text { абсолютних } \\
\text { значень, } \boldsymbol{M}\end{array}$ & & & 1 & 2 & 4 & 6 & 8 & 10 & 12 & 13 & 14 & 15 \\
\hline I & $2,5-3,0$ & I & $5,0-6,0$ & 2,7 & & & & & & & & & \\
\hline I & $2,5-3,0$ & IV & $2,0-3,0$ & & & & & & & & & 33,5 & \\
\hline II & $2,0-2,5$ & II & $4,0-5,0$ & 10,6 & & & & & & & & & \\
\hline II & $2,0-2,5$ & III & $3,0-4,0$ & & & & & & & 15,9 & & & \\
\hline II & $2,0-2,5$ & IV & $2,0-3,0$ & 2,1 & & & & 14,0 & & & & & \\
\hline III & $1,5-2,0$ & I & $5,0-6,0$ & 1,9 & & & & & & & & & \\
\hline III & $1,5-2,0$ & II & $4,0-5,0$ & 4,2 & & & & & & & & & \\
\hline III & $1,5-2,0$ & III & $3,0-4,0$ & 6,4 & & & 13,8 & & 23,9 & & & & \\
\hline III & $1,5-2,0$ & IV & $2,0-3,0$ & 8,5 & 50,8 & & 12,1 & 13,8 & & 17,8 & 78,3 & & \\
\hline III & $1,5-2,0$ & $\mathrm{~V}$ & $1,0-2,0$ & 2,2 & & & & & & 33,8 & 21,7 & 34,8 & \\
\hline IV & $1,0-1,5$ & III & $3,0-4,0$ & 2,3 & & & & & 25,2 & & & & \\
\hline IV & $1,0-1,5$ & IV & $2,0-3,0$ & 10,6 & & & 25,3 & & & 17,1 & & & \\
\hline IV & $1,0-1,5$ & $\mathrm{~V}$ & $1,0-2,0$ & 6,3 & & & & 15,1 & & 15,4 & & & 100 \\
\hline $\mathrm{V}$ & $0,5-1,0$ & IV & $2,0-3,0$ & 14,8 & & & 11,6 & & 24,7 & & & & \\
\hline $\mathrm{V}$ & $0,5-1,0$ & $\mathrm{~V}$ & $1,0-2,0$ & 25,3 & 49,2 & 67,4 & 24,7 & 57,1 & 26,2 & & & 31,7 & \\
\hline $\mathrm{V}$ & $0,5-1,0$ & $\mathrm{Va}$ & менше 1,0 & 2,1 & & 32,6 & 12,5 & & & & & & \\
\hline \multicolumn{4}{|c|}{ Індекс різноманітності розмірної структури (IDSS), \% } & 48,3 & 6,9 & 6,9 & 20,7 & 13,8 & 13,8 & 17,2 & 6,9 & 10,3 & 3,4 \\
\hline
\end{tabular}




\section{Розмірна структура когорт великого підросту Quercus robur}

\begin{tabular}{|c|c|c|c|c|c|c|c|c|c|c|c|c|}
\hline \multicolumn{4}{|c|}{ Морфометричні параметри } & \multirow{2}{*}{\multicolumn{9}{|c|}{$\begin{array}{l}\text { Частка особин різного розміру за групами асоціацій, \% } \\
\text { (нумерація груп асоціацій відповідає наведеній у тексті ) }\end{array}$}} \\
\hline \multicolumn{2}{|r|}{ висота } & \multirow{2}{*}{\multicolumn{2}{|c|}{$\begin{array}{c}\text { діаметр } \\
\text { амплітуда } \\
\text { абсолютних } \\
\text { значень, } \mathrm{cm}\end{array}$}} & & & & & & & & & \\
\hline клас & $\begin{array}{c}\text { амплітуда } \\
\text { абсолютних } \\
\text { значень, },\end{array}$ & & & 1 & 3 & 6 & 7 & 9 & 10 & 11 & 12 & 14 \\
\hline Ia & 68,0 & Ia & 69,0 & 10,6 & & 100 & & & 32,7 & & & \\
\hline I & $7,0-8,0$ & Ia & 69,0 & & & & & & & 30,8 & 32,1 & \\
\hline II & $6,0-7,0$ & Ia & 69,0 & 11,3 & & & & 74,3 & & 69,2 & & \\
\hline III & $5,0-6,0$ & Ia & 69,0 & & & & & & & & 34,7 & \\
\hline IV & $4,0-5,0$ & Ia & 69,0 & 9,3 & & & & & & & & \\
\hline Ia & 68,0 & I & $8,0-9,0$ & & & & 19,3 & & & & & \\
\hline I & $7,0-8,0$ & II & $7,0-8,0$ & & & & 20,1 & & & & & \\
\hline II & $6,0-7,0$ & $\mathrm{~V}$ & $4,0-5,0$ & & & & 22,9 & & & & & \\
\hline III & $5,0-6,0$ & I & $8,0-9,0$ & 22,1 & & & & & & & & \\
\hline III & $5,0-6,0$ & III & $6,0-7,0$ & & & & & & 34,3 & & & \\
\hline IV & $4,0-5,0$ & I & $8,0-9,0$ & 23,5 & & & & & & & & \\
\hline IV & $4,0-5,0$ & II & $7,0-8,0$ & 11,7 & & & & & & & & \\
\hline IV & $4,0-5,0$ & IV & $5,0-6,0$ & & & & 18,3 & & & & & \\
\hline IV & $4,0-5,0$ & $\mathrm{~V}$ & $4,0-5,0$ & & & & 19,4 & & & & & \\
\hline $\mathrm{V}$ & $3,0-4,0$ & II & $7,0-8,0$ & 11,5 & & & & & & & & \\
\hline $\mathrm{V}$ & $3,0-4,0$ & $\mathrm{~V}$ & $4,0-5,0$ & & & & & 25,7 & & & 33,2 & \\
\hline IV & $4,0-5,0$ & $\mathrm{Va}$ & м 4,0 & & 31,7 & & & & 33,0 & & & 34,2 \\
\hline $\mathrm{V}$ & $3,0-4,0$ & $\mathrm{Va}$ & м 4,0 & & 33,5 & & & & & & & 65,8 \\
\hline $\mathrm{Va}$ & м 3,0 & $\mathrm{Va}$ & м 4,0 & & 34,8 & & & & & & & \\
\hline \multicolumn{4}{|c|}{ Індекс різноманітності розмірної структури (IDSS), \% } & 18,4 & 7,9 & 2,6 & 13,2 & 5,3 & 7,9 & 5,3 & 7,9 & 5,3 \\
\hline
\end{tabular}


Загалом, визначені для кожної з когорт величини IDSS свідчать про прояв тенденції щодо зменшення різноманітності розмірної структури підросту в міру його дорослішання. Ця особливість ще більш чітко відслідковується на прикладі фітоценозів, у яких наявні всі три досліджувані когорти молодого покоління. Так, в угрупованнях групи асоціацій Pineta (sylvestris) hylocomiosa дрібний підріст $Q$. robur має значення IDSS $57,1 \%$, середній $-48,3 \%$, великий $-18,4 \%$. У лісах групи асоціацій Pineta (sylvestris) franguloso (alni)-vacciniosa (myrtilli) величина IDSS у дрібного підросту становить 50,0 \%, середнього - 20,7 \%, великого - 2,6\%. У групі асоціацій Querceto (roboris)-Pineta (sylvestris) vacciniosa (myrtilli) показник IDSS дрібного підросту 33,3\%, середнього - 13,8\%, великого - 7,9\%. У групі асоціацій Querceta (roboris) convallariosa (majalis) дрібний підріст має значення IDSS на рівні $31,0 \%$, середній $-10,3 \%$, великий $-5,3 \%$. Також у ряду дрібний підріст $\rightarrow$ середній підріст $\rightarrow$ великий підріст відбувається зростання дискретності спектрів, яке проявляється в частішому «випаданні» зі спектрів особин певного розмірного класу висоти (діаметра).

У досліджених фітоценозах найвищою різноманітністю розмірної структури вирізняється підріст Q. robur $з$ угруповань групи асоціації Pineta (sylvestris) hylocomiosa. Крім того, у сосняках зеленомохових серед підросту простежено високу частоту трапляння рослин, які за значеннями висоти, діаметра належать до найвищих розмірних класів (Іа-III). Тобто, виходячи з ознак розмірної структури, можна припустити, що в майбутньому в складі деревостанів низки лісів групи асоціацій Pineta (sylvestris) hylocomiosa може відбутися збільшення частки особин $Q$. robur.

Водночас молоде покоління Q. robur представлене під наметом лісів, де в материнському деревостані домінує дуб звичайний (групи асоціацій Querceta (roboris) majanthemosa (bifolii), Querceta (roboris) convallariosa (majalis), Querceta (roboris) coryloso (avellanae)-convallariosa (majalis)) характеризується досить невисокими (меншими за 31,0 \%) величинами IDSS. При цьому у фітоценозах формації Querceta roboris серед підросту $Q$. robur значну питому вагу складають рослини, величини висоти та (чи) діаметра яких відповідають найнижчим розмірним класам (III-Va) цих показників. Ці факти об' єктивно свідчать про ускладненість процесу природного відновлення в лісах цієї формації та, відповідно, про те, що в межах досліджуваного регіону дубовим лісам не притаманний високий рівень стійкості й здатності до самопідтримання.

Висновки та перспективи подальшого дослідження. Показники поширеності підросту Q. robur за фітоценозами та представленості в складі кожного 3 досліджуваних угруповань його когорт $€$ характеристиками, що об’єктивно свідчать про ускладненість природного відновлення цього виду на території Лівобережного Полісся України.

Кожна когорта підросту в тому чи іншому лісовому фітоценозі має специфічні особливості розмірної структури. У міру дорослішання підросту в когорт $Q$. robur чітко проявляється тенденція до зменшення різноманітності розмірної структури та зростання дискретності розмірних спектрів. Це $\epsilon$ наслідком поступового відмиранням у когортах частини рослин у процесі природного відновлення та формування в особин на завершальних його етапах більш чітко виражених морфологічних адаптацій до еколого-ценотичних умов місцезростань.

Ураховуючи те, що в низці фітоценозів, де зараз простежуємо природне відновлення Q. robur, у майбутньому може відбутися суттєва трансформація складу й структури деревостанів, уважаємо за доцільне розгортання на території Лівобережного Полісся України моніторингових досліджень за процесом самопідтримання лісових угруповань. Важливою їхньою складовою частиною повинен стати комплексний популяційний аналіз, методологія якого передбачає для молодого покоління провідних лісоутворювальних видів на ділянках відновлення здійснення оцінки різних типів структури, у тому числі розмірної.

\section{Джерела та література}

1. Бузун В. О. Структура соснових насаджень, що надходять у лісовідновні рубки / В. О. Бузун, О. Г. Дмитренко, В. Д. Шкудор // Лісівництво і агролісомеліорація. - 2004. - Вип. 107. - С. 126-130.

2. Дыренков С. А. Структура и динамика таежных ельников / С. А. Дыренков. - Л. : Наука, 1984. - 174 с.

3. Ипатов В. С. Деференциация древостоя / В. С. Ипатов // Вестник Ленинградского университета. Серия «Биология». - 1968. - № 21. - Вып. 4. - С. 59-68. 
4. Злобин Ю. А. Принципы и методы изучения ценотических популяций растений / Ю. А. Злобин. Казань : Изд-во Казанского ун-та, 1989. - 146 с.

5. Злобин Ю. А. Популяционная экология растений: современное состояние, точки роста / Ю. А. Злобин. Сумы : Университет. кн., 2009. - 263 с.

6. Карманова И. В. Математические методы изучения роста и продуктивности растений / И. В. Карманова. - М. : Наука, 1976. - 222 с.

7. Котов С. Ф. Конкуренция и размерная структура ценопопуляций Salicornia europaea L. (Chenopodiaceae Vent.) / С. Ф. Котов // Ученые записки Таврического национального университета им. В. И. Вернадского. - Серия «Биология». - 2001. - Т. 14 (53), № 1. - С. $43-49$.

8. Лебков В. Ф. Закономерности и оценки структуры древостоев сосны / В. Ф. Лебков, Н. Ф. Каплина // Лесное хозяйство. - 2008. - № 3. - С. 39-41.

9. Лопатникова О. А. Естественное возобновление в коренных северотаежных сосновых лесах Карелии / О. А. Лопатникова, Е. В. Шорохова // Современные проблемы и перспективы рационального лесопользования в условиях рынка. - СПб., 2008. - С. 28-32.

10. Мелехов И. С. Лесоведение / И. С. Мелехов. - М. : Лесная промышленность, 1980. - 405 с.

11. Оскорбин П. А. Структура темнохвойных древостоев южной тайги Красноярского края : автореф. дис. ... канд. биол. наук / П. А. Оскорбин - Красноярск, 2007. - 17 с.

12. Полевая геоботаника : [в 4 т]. - М. ; Л. : Наука, 1964. - Т. 3. - 530 с.

13. Скляр В. Г. Внутрішньопопуляційна структура та методика її вивчення у деревних лісоутворюючих видів / В. Г. Скляр, Ю. А. Злобін // Чорноморск. ботан. журн. - 2013. - Т. 9, № 3. - С. 316-329.

14. Сукачев В. Н. Методические указания к изучению типов леса / В. Н. Сукачев, С. В. Зонн. - М. : АН CCCP, 1961. - $143 \mathrm{c}$

15. Hunt R. Plant growth analysis / R. Hunt. - London, 1978. - 67 p.

16. Marba N. Allometric scaling of plant history / N. Marba, C. Duarte, S. Agusti // Proc. Nation. Acad. Sci. USA. 2007. - Vol. 104. - P. 15777-15780.

17. Weiner J. Size hierarchies in experimental populations of annual plants / J. Weiner // Ecology. - 1985. Vol. 66, № 3. - P. 743-752.

Скляр Виктория. Размерная структура подроста дуба обыкновенного в лесных фитоценозах Левобережного Полесья Украины. Представлена информация о высоте и диаметре ствола особей разных групп молодого поколения дуба обыкновенного, растущих под пологом лесных фитоценозов 17 групп ассоциаций, типичных для Левобережного Полесья Украины. Охарактеризована размерная структура трёх когорт подроста: мелкого, среднего и крупного. Показано, что каждая из них в том или ином лесном фитоценозе имеет специфические особенности размерной структуры. Для детальной оценки размерной структуры когорт предложен и использован специальный показатель - индекс разнообразия размерной структуры (IDSS). Показано, что в основном когорты подроста дуба обыкновенного не отличаются высоким уровнем разнообразия размерной структуры: значение IDSS в большинстве фитоценозов не превышает $25 \%$. В целом отмечена тенденция к уменьшению разнообразия размерной структуры по мере взросления подроста.

Ключевые слова: лесообразующие виды, естественное возобновление лесов, подрост, морфометрический анализ, дуб обыкновенный

Skliar Viktoria. Size Structure Undergrowth of Quercus Robur in Forests of Left Bank Ukraine Polissya. Presents information about the height and the diameter of the trunk individuals of different groups of the young generation of Quercus robur, growing under the canopy of forest phytocenoses 17 groups of associations typical of the Left Bank Polissya of Ukraine. Characterized three-dimensional structure of the cohorts of undergrowth: small, middle and large. It is shown that each cohort in a particular forest communities has specific features dimensional structure. For a detailed assessment of the size structure of cohorts proposed and used a special rate: index diversity of size structure (IDSS). Basically cohort undergrowth of Quercus robur have not a high level of diversity of size structure: the value IDSS most phytocenoses does not exceed $25 \%$. There was a trend to a decrease in the diversity of size structure as they grow older regrowth.

Key words: forest-forming species, natural regrowth of forest, undergrowth, morphometric analysis, Quercus robur

Стаття надійшла до редколегії 25.09.2015 p. 